\title{
New observations on the asexual reproduction of Aurelia aurita (Cnidaria, Scyphozoa) with comments on its life cycle and adaptive significance
}

\begin{abstract}
Alejandro A. Vagelli
New Jersey Academy for Aquatic Sciences. 1 Riverside Drive, Camden. N. J. 08103. U.S.A.

e-mail:avagelli@njaas.org

ABSTRACT: Two previously unreported asexual reproductive mechanisms have been observed in Aurelia aurita (Linnaeus, 1758). In one, scyphistomae produce internally several planula-like propagules that are released through the oral cavity and pass through a planktonic stage before settlement and metamorphosis. The second consists in the generation of free-swimming planuloids which are extruded through the external body wall of the scyphistomae. In contrast to the various budding process described in scyphozoans, both new mechanisms produce ramets that do not develop adult scyphistoma morphology prior to their release, and they only do so after passing through a free-swimming period that lasts up to several weeks.
\end{abstract}

KEY WORDS: planuloids, dispersal, metagenesis, gemmation.

\section{Новые сведения о бесполом размножении Aurelia aurita (Cnidaria, Scyphozoa), замечания о жизненном цикле и его адаптивном значении}

\begin{abstract}
А.А. Вагелли
New Jersey Academy for Aquatic Sciences. 1 Riverside Drive, Camden. N. J. 08103. U.S.A. e-mail: avagelli@njaas.org

РЕЗЮМЕ: Два ранее неизвестных способа бесполого размножения обнаружены у Aurelia aurita (Linnaeus, 1758). В одном случае внутри сцифистомы образуются планулоподобные пропагулы, выходящие через ротовое отверстие и проходящие перед оседанием и метаморфозом планктонную стадию развития. Во втором случае образуются свободноплавающие планулоиды, выделяемых через наружный покров тела сцифистомы. В отличие от разнообразных способов бесполого размножения известных у сцифозойных, оба новых способа бесполого размножения ведут к образованию особей, приобретающих облик взрослой сцифистомы не перед отделением от материнской особи, а после прохождения свободноплавающей стадии, длительность которой может достигать нескольких недель.
\end{abstract}

КЛЮЧЕВЫЕ СЛОВА: планулоид, расселение, метагенез, бесполое размножение. 


\section{Introduction}

The life stages and various reproductive mechanisms of Aurelia aurita (Linnaeus) have been the classic example of the scyphozoan life cycle for invertebrate textbooks, and the subject of many scientific papers on development and reproductive mechanisms (Agassiz, 1860, 1862; Haeckel, 1881; Lambert, 1935; Berrill, 1949), budding (Perez, 1922; Renton, 1930; Gilchrist, 1937), strobilation (Spangenberg, 1971, 1974; Olmon, Webb, 1974; Kato et al., 1973; Balcer, Black, 1991) life stages (Spanenberg, 1965; Lucas, 2001), and recruitment of planula larvae (Grondal, 1989). Also, several works have been published on podocyst production (Chapman, 1966, 1968, 1970), and regeneration (Lesh-Laurie, Corriel, 1973; Steinberg, 1963) for this species. However, the production of free-swimming propagules was not previously documented for A. aurita. Moreover, despite detailed reports of important variations on A. aurita ontogeny (e.g., Haeckel, 1881; Berrill, 1949; Thiel, 1966, Kakinuma, 1975), its life cycle is still commonly depicted in a simplified manner (e.g., Grondahl, 1988; Pechenik, 1991) even when it is utilized to base models of dispersion and patterns of distribution (Dawson, et al., 2005).

Scyphistomae of Aurelia aurita have been kept in culture for ten years with the goal of obtaining medusas for public display. During this time, strobilation has been induced and the processes of budding, regeneration, cyst production, and production of free-swimming propagules observed several times. This paper reports two previously undocumented asexual reproductive mechanisms in scyphistomae of $A$. aurita, in which the internal and external production of free-swimming planuloid propagules are involved. In addition, the life cycle of this species as it is known to date is reviewed, as well as discusses its adaptive significance.

\section{Materials and methods}

General conditions

Scyphistomae of Aurelia aurita were kept attached on sixteen $10 \times 5 \mathrm{~cm}$ plastic sheets submerged in four 30-1 tanks (four sheets in each tank). As the scyphistomae reproduced by budding and spread along the plastic sheets, portions were transferred to more plastic sheets and to forty 10-cm Petri dishes (polyp dishes). The new plastic sheets and Petri dishes were equally divided into two 100-1 tanks. All six tanks flowed together in a recirculating system consisting of a pump, a 120-1 sump, a biofilter and a chiller. Artificial seawater was used throughout the study for both tanks and Petri dishes. The salinity range was $30-33 \%$. The $\mathrm{pH}$ varied between 7.8 and 8 , while nitrites and ammonia remained at $0 \mathrm{mg} / \mathrm{l}$. Water temperature was maintained at $22^{\circ} \mathrm{C}$ except when strobilation was being induced. The system was kept covered from light to avoid algae growth, and no aeration was provided. Scyphistomae were fed (ad lib.) four times a week with newly hatched Artemia salina.

Scyphistomae observations and collection of gemmae and free-swimming buds

An Olympus SCH dissection microscope (7.5-64 x) was utilized to regularly observe scyphistomae attached to the polyp dishes. Microphotographs were taken with an Olympus PC $35 \mathrm{~mm}$ camera attached to the microscope, and an Olympus SH2 (1000 x) light-microscope was used to observe planuloid development. To follow daily migration of internal produced propagules, individual scyphistomae were distinguished by marks on the polyp dish bottoms. Once propagules were observed in a particular scyphistoma, they were photographically documented, and a fine mark was made on the polyp dish bottom to note the current position of each propagule.

To collect internally produced propagules from the scyphistomae gastrovascular cavity, a fine tuberculin needle was used to gently touch the oral area. This produced a quick reflex consisting of a stalk shortening and the opening of the oral cavity. A $400 \mu \mathrm{m}$ glass pipette was then used to remove the propagules, which were isolated into 5-cm Petri dishes (planuloid dishes) containing salt water filtered through a 0.45 $\mu \mathrm{m}$ membrane filter. Also, free (non-artificially 
extracted) internally generated propagules and free-swimming externally produced planuloids found in polyp dishes, were transferred to individual planuloid dishes to facilitate the study of their individual development.

All planuloid dishes were kept floating in both 100-1 tanks. When propagules developed gastrovascular openings and the first tentacle, they were fed rotifers (Brachionus plicatilis), and after the development of the second tentacle, they were fed newly hatched Artemia sali$n a$ nauplii. Water was replaced daily by new filtered sea water, approximately three hours after feeding.

\section{Results}

\section{Internal production of Free-Swimming Propagules (IFSP)}

IFSP were produced from the internal body wall of the gastrovascular cavity and stolons. Scyphistomae liberated several IFSP (usually between three and five) at the same time. Internal FSP slowly migrated from stolons and the aboral region to the oral region (Figs $1 \mathrm{~A}-\mathrm{C}$, $2 \mathrm{~A})$. The time necessary for the propagules to migrate from the aboral region to the oral opening was between one and three days and depended primarily on the distance from where they were produced.

After reaching the gastrovascular cavity, IFSP remained up to three days before they were released. The actual process of expulsion was very rapid (Fig. 2B,C). The opening of the oral cavity and release of IFSP did not take more than one or two seconds. The number of IFSP observed in any scyphistomae varied between three and six, and all migrated and were released simultaneously.

Internal FSP were spherical-ovoid structures of approximately $200 \mu \mathrm{m}$ in diameter. They were very consistent in shape and size, and were formed by an external layer of clear ectoderm covering a small core of darker endoderm. During the free stage, IFSP swam in a rotary manner by means of a ciliate layer of ectodermic cells resembling planula larvae. After release, they spent two to three weeks in as a free-swimming stage before settling down and attaching.

Metamorphosis began with an oral-aboral elongation followed by the opening of the gastrovascular cavity. Soon thereafter, the first two tentacles developed (Figs 2D, 3A). Generally the first tentacle began to differentiate, while the second followed one or two days later. Four to six days afterward, two more tentacles began to develop simultaneously. Depending upon the availability of food and on water quality, new scyphistomae developed eight tentacles in three to four weeks and sixteen tentacles after three more weeks.

\section{External production of Free-Swimming propagules (EFSP)}

The production of EFSP by scyphistomae of Aurelia aurita was characterized by the release of large free-swimming planuloids from the external surface of scyphistomae. The EFSP developed as outgrowths protruding usually from the lower half of the stalk and stolons (Fig. 3B,C). Although they had a broad range of forms and sizes, reaching up to one half of the scyphistoma size, most EFSP measured between 200 and 800 $\mu \mathrm{m}$. They usually have a spherical shape, although cylindrical and polyhedral also were observed. Besides the different location of origin, EFSP differed from IFSP by their compact and massive consistency, their brown-orange coloration, and their low motility. In addition, they require a considerably longer time to settle and develop adult structures once detached from the scyphistoma parent. It was common for EFSP to start metamorphosis four or five weeks after detaching.

\section{Discussion}

\section{Production of IFSP}

Differences and similarities with other processes

Lambert's "cysts"

In his description of the "Hydra Tuba" stage, Lambert (1935) mentioned that it can produce 


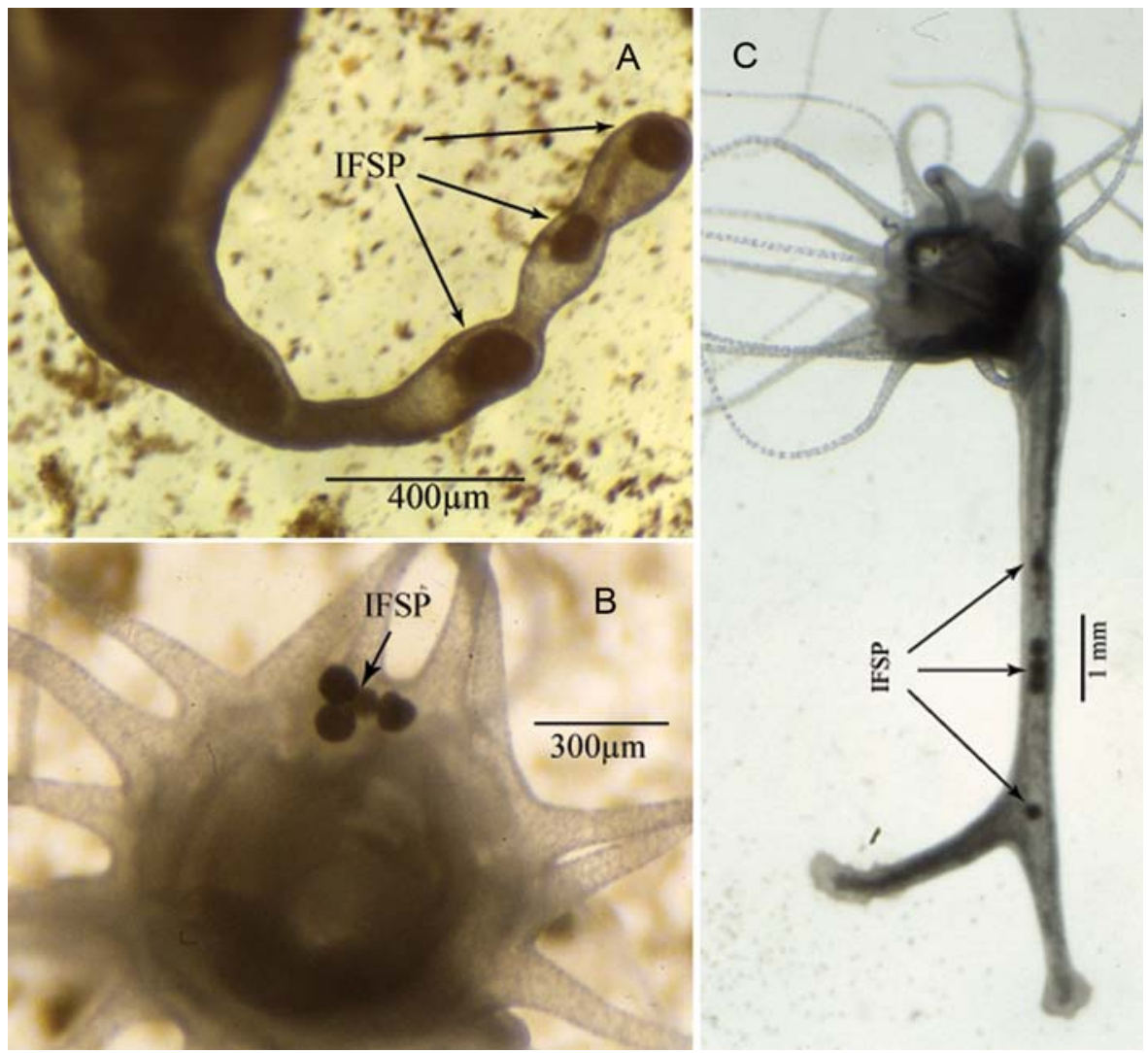

Fig. 1. Aurelia aurita (Linnaeus).

A - scyphistoma carrying three internally produced free swimming propagules (IFSP) in lower part of the stalk. In contrast to buds, these compact ciliated masses of cells are originated internally. B - scyphistoma with four IFSP close to release time, localized in the upper part of the gastrovascular cavity. C - five IFSP migrating inside of the scyphistoma stolon towards the oral region. IFSP normally took between one and three days to reach the oral cavity.

Рис. 1. Aurelia aurita (Linnaeus).

A - сцифистома с тремя свободноплавающими пропагулами (IFSP), выделяемыми в гастроваскулярную полость в нижней части ножки. В отличие от наружных почек эти компактные скопления реснитчатых клеток выделяются в гастроваскулярную полость. В - сцифистома с четырьмя готовящимися к выходу пропагулами IFSP в верхней части гастроваскулярной полости. C - пять пропагул IFSP, перемещающихся внутри столона сцифистомы к ротовому отверстию. Движение к ротовому отверстию пропагулы IFSP занимает от одного до трех дней.

numerous buds, send out shoots, "and in Aurelia push out cysts, a sort of egg (as with the freshwater Hydra), which can develop into a Hydra tuba in fourteen days."

It is uncertain what Lambert meant by "cysts." Hydra releases its eggs by extrusion of its wall tissue (Hyman, 1940) and not through its oral opening; it is unlikely that Lambert observed the release of internally produced propagules. Furthermore, IFSP are ciliated, do not have a "cyst-like cover" (theca) as Hydra eggs have, and take much longer to develop into scyphistomae.

On the other hand, it seems that "Lambert's cysts" are not related to podocysts either. Although Lambert compared the "cysts" with $H y$ dra eggs, Hydra eggs grow from the stalk and not from the attachment disk where podocysts originate.

In his review of Scyphomedusae development, Berrill (1949 pp 399) stated "locomotion of the scyphistoma has led to a special method 


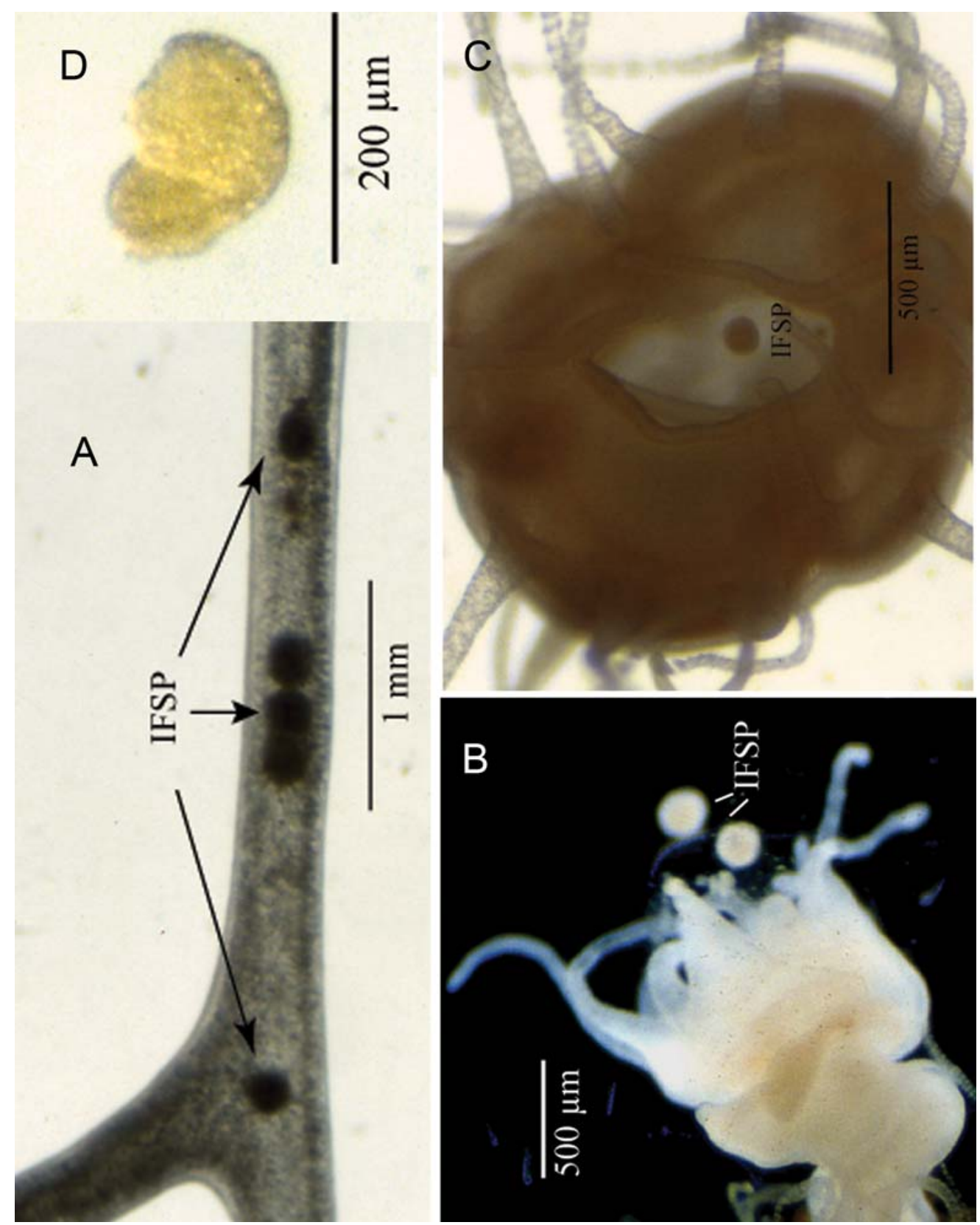

Fig. 2. Aurelia aurita (Linnaeus).

A - scyphistoma showing internally produced free swimming propagules (IFSP) with larger power. B — two IFSP released simultaneously. C - an IFSP is released through the scyphistoma oral opening. The expulsion process takes no more than two seconds. D - an IFSP began to develop its first tentacle (t). Before settling and transforming into scyphistomae it spent about 14 days in a free-swimming stage.

Pис. 2. Aurelia aurita (Linnaeus).

A - сцифистома с пропагулами IFSP, бо́льшее увеличение. В - две пропагулы IFSP, высвобождающиеся одновременно. C - пропагула IFSP, выходящая через ротовое отверстие сцифистомы. Выход пропагулы занимает не более двух секунд. D - пропагула IFSP на начальном этапе развития первого щупальца (t). Свободноплавающая стадия длится около 14 дней и завершается оседанием и превращением в сцифистому. 

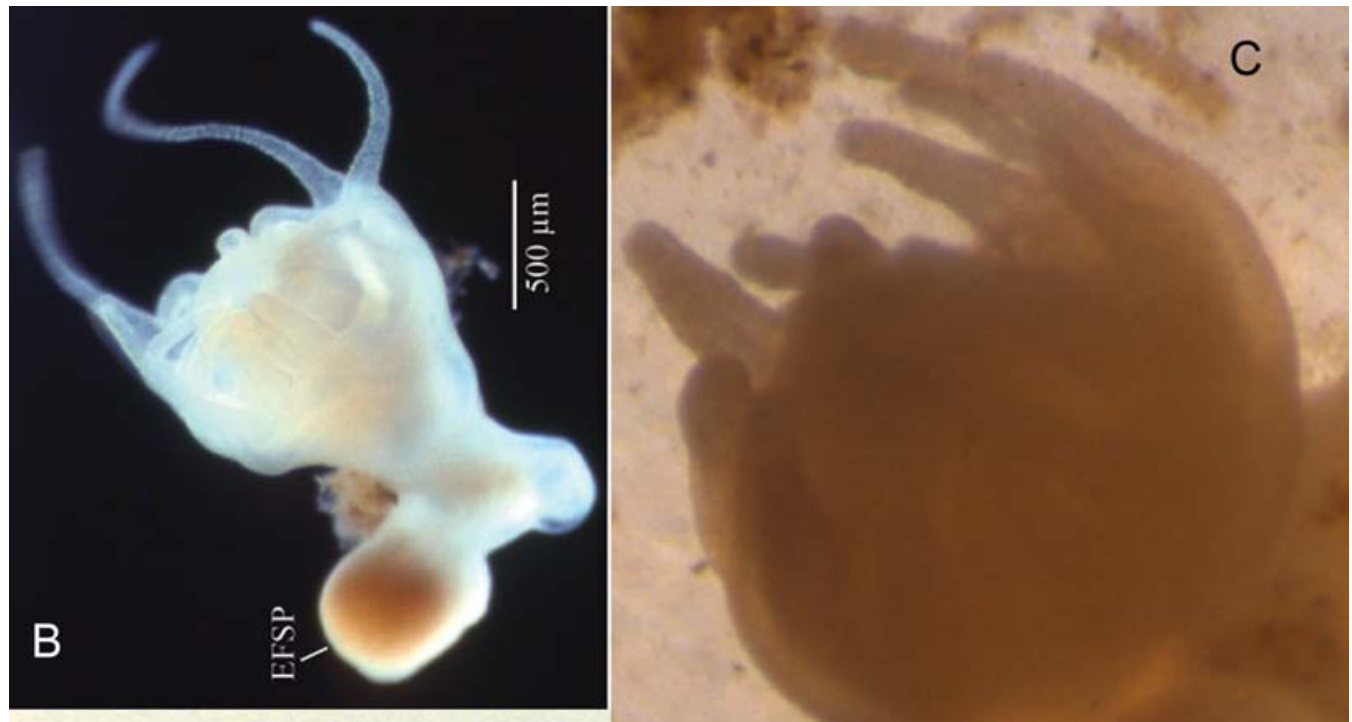

\section{A}
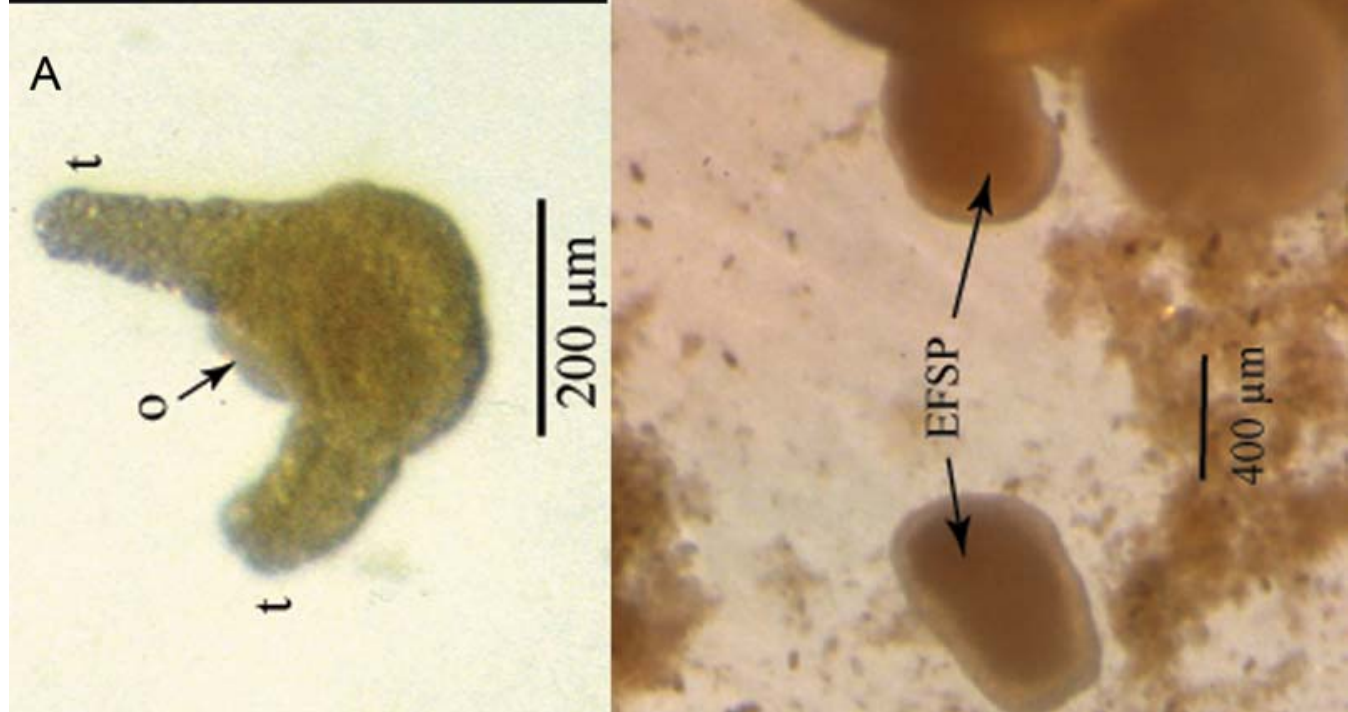

Fig. 3. Aurelia aurita (Linnaeus).

A - internally produced free swimming propagule (IFSP) two days after settlement, with the first two tentacles (t) and oral cavity (o) already developed. B-C - externally produced free swimming propagules (EFSP) were originated by extrusion of the body wall tissue in a "budding-like" process. EFSP never developed adult scyphistomae structures while attached to the scyphistoma parent. EFSP larger, less consistent in shape and size, and less motile than the IFSP.

Рис. 3. Aurelia aurita (Linnaeus).

A - пропагула IFSP через два дня после оседания с двумя щупальцами (t) и ротовым отверстием (o). B-C пропагула EFSP образуется экструзией стенки тела подобной почкованию. Пропагулы EFSP не превращаются во взрослых сцифистом во время их прикрепления к материнской особи. Они в отличие от пропагул IFSP крупнее, более изменчивы и менее подвижны.

of reproduction" and mentioned the production of cysts by Chrysaora hyoscella and the observations of Herouard (1907), Hadzi (1912), and Chuin (1930) on statoblasts. However, he did not include Lambert's observations on "cyst" production. Chapman (1966:60), who made the first detailed description of the nature, production, and historic review of podocysts (includ- 
ing the observations made by Verwey, 1960 in Cyanea, and by Chuin, 1930 in Chrysaora), did not mention Lambert "cysts" either, although he did point out Lambert's observations on the capacity of scyphistoma to tolerate stagnant water conditions.

\section{Pseudoplanula tentacularies}

Morphologically, IFSP resemble the "pseudoplanula tentacularies" described by Herouard (1913). He observed scyphistomae of Chrysaora passing through a "depression period", losing their tentacles, and transforming themselves into "pseudoplanulas" by reducing their volumes. However, IFSP occurred only during periods of scyphistomae growth under favorable environmental conditions (good water quality and intense feeding). Furthermore, IFSP were released as undifferentiated masses of cells that increased rather than decreased their volumes during their transformation into scyphistomae.

\section{Regeneration}

In his experiments on regeneration of scyphistomae of Aurelia aurita, Gilchrist observed that "entodermal pieces round up into ciliated balls, which may remain alive and rotating for several days, but which do not regenerate. Pieces of ectoderm, on the other hand, round up, and within a period of 7 to 11 days regenerate small, complete polyps" (Gilchrist, 1937: 111).

In experiments on the effect of attachment on polyp regeneration, Kakinuma (1975) observed that small pieces of polyp tissue after two days cohered into spherical and ciliated masses. If the masses were allowed to attach, one third of them formed polyps and developed tentacles after seven-eight days, and all masses became polyps by the tenth day.

Lesh-Laurie and Corriel (1973: 888) described the locomotion of isolated tentacles as "discontinuous circular movement about the substrate with the proximal end always in advance." They found that isolated tentacles that survived for five weeks all regenerated successfully, and depending upon their origin (oralring, whole or distal third), tentacles took from three to six weeks to regenerate new scyphistomae. Complete or final scyphistoma form was defined as "when regenerates had attached to the substrate, formed a mouth encircled by a ring of 4-8 newly developed tentacles and were capable of feeding".

Several times during this study, small pieces of scyphistomae (commonly from tentacles) were cut off during transfers of scyphistomae from plastic sheets to culture dishes. After isolation in "planuloid" dishes, they were always transformed into spherical ciliated masses, very similar (except their larger size) to IFSP.

In spite of their different origin and mode of production, IFSP (after release) behaved similarly to regenerating scyphistomae fragments, and took approximately the same time to transform themselves into adult scyphistomae.

\section{Production of EFSP}

Differences and similarities with other described processes

\section{Berrill's Type I budding}

Berrill (1949) classified the budding modes of Scyphomedusae into six types. He defined his Type I as: "Buds grow as a wide diverticula of the body wall; they are set free and swim away before any significant morphogenesis, original proximal end becoming the oral disc." Berrill included Cotylorhiza tuberculata, C. xamacha$n a$, and (citing Lambert's 1935 work) "possibly occurring at times in Aurelia aurita." However, Lambert's 1935 budding classification is not clear. He described "hydra tubae" budding in three ways, i. e., "(1) by direct growth from the outer wall of the body with, generally, early liberation. (2) By means of the lateral process with immediate liberation; and (3) By means of stolonic outgrowths, the buds sometimes being liberated but more often remaining as colonies surrounding the parents." Lambert stated that all three forms of budding are found in Aurelia; that Chrysaora and 'Rentoni' (referring to the unspecified scyphistoma whose budding process Renton described) buds by lateral process alone (Lambert \#2); that Cyanea capillata buds 
chiefly by stolons (Lambert \#3), and that in ' $C$. Lamarckii' the buds move away.

Budding in both Chrysaora and 'Rentoni' (Lambert \#2) had been described in detail, e. g., Perez (1922), Renton (1930), Gilchrist (1937) and none of these descriptions agree with an "immediate liberation" of buds. Thus, Lambert's Type 2 budding mode corresponds to Berrill's Type 3, not Type 1 (Berrill 1949). In addition, Lambert's Type 3 is associated with outgrowth of pedal stolons (Berrill's Type 4 not Type 1).

Hence, when Berrill includedAurelia aurita (citing Lambert's observations) together with Cotylorhiza tuberculata and Cassiopea xamachana, which both produce typical rhizostomid free-swimming planuloids, in his budding Type I, he probably was referring to Lambert's “cysts," not to Lambert's classification of buds.

Free-swimming planuloids in rhizostomids

The production of free-swimming planuloids is well known in rhizostomids, e. g., Cassiopea andromeda (Hofmann et al., 1978), Cassiopea xamachana (Bigelow, 1900; Curtis, Cowden, 1971; Van Lieshout, Martin, 1992), Mastigas papua (Sugiura, 1963), and Cotylorhiza tuberculata (Claus, 1893). Hofmann et al. (1978 pp.172) pointed out that the budding process described for most rhizostomid species is "an entirely different type" than those described for semaeostomids. However, they mentioned that "strict classification according to the mode of asexual reproduction is not possible, since Rhizostoma pulmo, as indicated by the observations of Paspaleff (1938), seems to exhibit almost every known type of vegetative polyp formation" including planula-like buds, Hydra-type buds, and stolonial buds. Also, Calder (1973) found that Rhopile$m a$ verrilli differs from the other rhizostomids in producing stolons and podocysts, but not free-swimming buds.

Several differences exist between freeswimming propagules produced by Aurelia aurita and those produced by the above described rhizostomids; e. g., Cassioipea xamachana planuloids possess a well-defined me- soglea, septal muscles, and they swim by rotating around the longitudinal axis of their body (Hofmann et al., 1978; Lesh-Laurie, Suchy, 1990; Van Lieshout, Martin, 1992; personal observations). In contrast, propagules from $A$. aurita do not have a distinct mesoglea or septal muscles; Aurelia's EFSP are much less motile, swim without direction, and lack any clear body axis.

The production of IFSP and EFSP by Aurelia aurita and planuloids by rhizostomids share two basic characteristics that differentiate this type of vegetative multiplication from typical budding processes described in semeaostomes and other groups, including the production of lateral buds, stolonic buds, pedal stolons, hydra-type buds, and fission buds. First, neither IFSP or EFSP develop adult scyphistomae structures while they are attached to the parent; second, once released IFSP and EFSP adopt a planula like appearance and swim for a variable period of time before settling and transforming into a new scyphistomae. In addition to these morphological and developmental differences, the production of free-swimming propagules can be expected to have important ecological implications having to do with dispersal, recruitment, and intraspecific competition. Thus, the production of free-swimming planuloids described in most rhizostomid and the production of free-swimming propagules in Aurelia aurita should be considered a distinct asexual reproductive mechanism instead of another type of budding. It is proposed the term "gemmation" for referring to this mechanism and "gemmae" should be used for the products of this mechanism. This will avoid confusion with the term "budding" that has been used to refer to a large number of unrelated vegetative multiplication processes in all groups of cnidarians (Fautin, 2001).

\section{Review of Aurelia aurita life cycle and its adaptive significance}

The life cycle of Aurelia aurita includes the alternation of two dimorphic generations, medusa and scyphistoma, that are also very distinct 
ecologically and physiologically. In addition, one generation reproduces sexually, while the other reproduces asexually (metagenesis). Most studies on life cycles, reproductive strategies and dispersal of marine clonal species do not include organisms with complex life cycles like that of Aurelia aurita (e.g., Ayre, 1984; Jackson, 1986; Jackson, Coates, 1986; Jaeckle, 1994; Mc Fadden, 1997; Thorson, 1950; Vance, 1973). Despite debating the dispersal contribution of asexually vs. sexually produced propagules of a variety of species, the resulting different genetic structures within (clonal and aclonal) populations, and their adaptive significance, these studies are all based on organisms for which (a) adult individuals are sessile or have minimal dispersal capabilities (except rafting), (b) sexual reproduction occurs in fixed locations (parental habitat), (c) dispersal relies almost completely on larval forms, sexually or asexually produced, that only last from a few minutes to a few weeks.

In contrast, the life history of Aurelia aurita: (a) combines sessile and free-living planktonic adults $^{1}$, (b) sexual reproduction is independent of the benthic-sessile stage and potentially occurs over continuous wide-ranging geographical areas, and (c) both larval and adult stages have dispersal capabilities which extend from a few days (planula), to weeks (IFSP, EFSP, ephyra), to several months or more (medusa). Once alternation of generations (and metagenesis) is taken into consideration, theories dealing mainly with benthic invertebrates do not provide an accurate description of the adaptive significance of different life stages of organisms like most scyphozoans with an alternation of generations.

${ }^{1}$ Both the scyphistoma and the medusa forms are considered here as distinct phenotypes with their own ontogeny. Thus, the medusa phenotype passes through a series of morpho-physiological changes from the newly metamorphosed ephyra to the mature and to the senescence stage; and the scyphistoma phenotype from the various stems forms such as planula, cyst, free swimming propagule, and bud to the adult stage, i.e., with complete number of tentacles and capable of reproducing. For theories dealing with ontogenetic and phylogenetic sequence of life cycle stages, see Hyman (1940), Hadz (1953), Hand (1959), Thiel (1966), and Chapman (1966).

\section{Sexual phase}

\section{Sex determination}

It seems that the issue of the point in Aurelia aurita's life cycle where sex first differentiates and its potential implications has been mainly overlooked. As far as it is known, no studies have been done to establish the genetic, physiological, and / or environmental mechanisms of sex determination in either the medusa or scyphistoma phenotypes.

If scyphistoma germinal stem cells do not participate in gonad formation, gametogenetic tissue would develop anew in the medusa phenotype and sex would be determined at some point during the medusa development. In this case, if sex were genetically controlled, and since all medusae originating from a given scyphistoma share the same genotype, then all medusae produced by such scyphistoma should have the same sex. On the other hand, if phenotypic sex were environmentally determined at the medusa stage, it would be expected that populations of scyphistomae strobilating under the same environmental conditions, would produce ephyrae that would develop the same type of gonad. It has been reported that temperature determines the phenotypic sex in the dioecious Hydra oligactis (Littlefield, 1986), and Carre and Carre (2000) showed how temperature at strobilation time significantly (but not completely) determines the phenotypic sex in medusae of Clytia hemisphaerica, a marine dioecious hydrozoan with alternation of generations.

Spanenberg (1965) raised 96 medusae of Aurelia aurita until sexual maturation under laboratory conditions. The medusae derived from scyphistomae that in turn originated from planulae released by female medusae collected in the wild. All ephyrae and medusae were kept in artificial seawater and at $21-24^{\circ} \mathrm{C}$. Sexual maturity was observed in about $42 \%$ of the medusae. Sperm sacs were found at 38, 39 and 112 days, and planula larvae on days 88 and 153 . In contrast, only male medusae were observed to reach sexual maturity in our laboratory. The main difference from Spanenberg's holding conditions was our lower water temperature, 
about $17^{\circ} \mathrm{C}$ during the first four months after strobilation, and about $22^{\circ} \mathrm{C}$ thereafter.

These observations may suggest that the phenotypic sex at the medusa stage to be mostly environmental controlled, e. g., under lower temperatures only male gonads develop, whereas in warm conditions germinal tissue has the potential to differentiate into both gonads equally. Altough lower temperature decreases medusae growing rates, and female medusae seems to need longer to achieve sexual maturation than males, it is highly improbable that the absence of female medusae in our facility was related to developing time. Several works have shown a lack of relationship between gonad development, size and age. For instance, whereas our medusae attained a bell diameter of at least between $80-100 \mathrm{~mm}$ before being replaced (usually after five-six months), Lucas (1996) found females as small as 19-20 mm carrying eggs and planula larvae in Horsea Lake (England). In addition, Spanenberg's largest medusae reached a bell diameter of only $55 \mathrm{~mm}$, and she found no correlation between age and development of morphological structures (subgenital pits were observed to develop between 25 and 66 days). Similarly, Lucas and Lawes (1998) found that size at maturity is not correlated with either age or bell diameter in wild populations. Ripe females were found at such small size as $19 \mathrm{~mm}$ in bell diameter and as early as 90 days after strobilation. Therefore it seems that our medusas would have had enough time to develop female gonads if they were genetically determined.

On the other hand, both Spanenberg's laboratory work, and Lucas and Lawes' field study (where individuals are subjected to similar environmental conditions, and a temperature range between 5.5 and $23^{\circ} \mathrm{C}$ ) show that under same environmental conditions both sexes develop, which would indicate that phenotypic sex is most likely genetically determined.

If sex differentiation in medusae is genetically determined and gonad development is not closely related to age, then one possible explanation for the observations of only male medusae sexually maturing (and no detection of female medusae) in our facility could be that medusae phenotypic sex in A. aurita is determined at the scyphistoma stage, rather than at medusae stage. If the medusa phenotypic sex is determined at the scyphistoma stage, and it is genetically controlled, all ephyrae that metamorphosed into medusae should have the same genetic composition of the particular strobila from which they derived. It is possible that we had started with an only male population of scyphistomae, and all derived ephyrae developed male gonads, independently of the environmental conditions (our original population consisted of five plastic sheets 10 x 5 cm carrying attached scyphistomae, and it was never mixed with scyphistomae from other sources).

Lesh-Laurie and Suchy (1990) mentioned the observations by Komai (1935) and Werner (1970) on germ cell formation on scyphistomae of the coronate Stephanoscyphus. The only known instance of gametogenesis occurring in a scyphopolyp. Mature germ cells were incorporated into the ephyra during strobilation, but no gametes were found in such ephyrae. Chapman (1966) pointed out the tendency for scyphistomae to form gonads, which may even persist in the strobila and ephyra. He described the formation of sex cells, which were intermediate between sperm and ova (neutral gonad), but he also suggested that germ cell development in scyphistomae was weakly genetically determined.

Also, it could be possible that the medusa phenotypic sex be determined at the scyphistomae stage but remain under environmental control. In this case it would be expected that all medusae derivate from the same scyphistoma will have the same sex, but genetically identical scyphistomae maintained under different ambient conditions will produce medusae of different sex.

\section{Gonad and embryo development}

It is well known that sexual reproduction is carried out by the gonochoristic medusa phenotype. Studies on lab-raised specimens showed that sexual maturity of medusae can be attained in about 40 days for males and 90 days for females at $21-24^{\circ} \mathrm{C}$ (Spanenberg, 1965), al- 
though field observations by Lucas (1996) in Horse Lake suggest that medusae growing at lower temperatures and exposed to periods of food limitations likely take significantly longer to mature. In their study of growth and degrowth in a population of $A$. aurita from Tomales Bay (California), Hamner and Jenssen (1974) found that gonads from mature medusae deprived of food regressed to immature state within five to eight days. After 40 days of starvation, the medusae that were fed grew to full size and become sexually mature again. During their 130day laboratory study, they observed some medusae spawning and becoming sexually mature again within a two-week period, without postspawning gonadal or somatic deterioration.

Eckelbarger and Larson (1988) found that the process of yolk deposition was both autosynthetic and heterosynthetic, and vitellogenesis was completed in less than four days if abundant food is available. Oogenesis is asynchronous, without a maturation gradient, and oogonia differentiate without a pattern within the endoderm. There is a high degree of variability in oocyte and planula larvae size composition within populations; yolk deposition starts in oocytes of about $75 \mu \mathrm{m}$ in diameter, and mature oocytes range between about 75 and 180 $\mu \mathrm{m}$ (Widersten, 1965; Eckelbarger, Larson, 1988; Avian, Sandrini, 1991; Lucas, Lawes, 1998).

Spermatogenesis is synchronous; takes about eight days at $17^{\circ} \mathrm{C}$ and is independent of developmental control mechanisms that regulate cellular phenomena in the rest of the organism; once spermatogenesis begins, germ cells complete differentiation in spite of gonad and organism regression (Hamner, Jenssen, 1974). Sperm develops in follicles located in the genital mesoglea; after release, it is transported by ciliary currents though the female gastrovascular cavity and fertilization takes place at the ovarian genital sinus (Widersten, 1965).

Ishii and Takagi (2003) described the embryo development. Cleavage was holoblastic and time from zygote to gastrula varied from $116 \mathrm{~h}$ at $12^{\circ} \mathrm{C}$ to $50 \mathrm{~h}$ at $22^{\circ} \mathrm{C}$, and from gastrula to planulae release about $154 \mathrm{~h}$ at $12^{\circ} \mathrm{C}$ to $120 \mathrm{~h}$ at $22^{\circ} \mathrm{C}$. Development of planulae occurs within brood pouches located in the walls of the females' oral arms (Agassiz, 1862; Russell, 1970, Kakinuma, 1975). Planula larvae have been reported measuring from about 20 to $80 \mu \mathrm{m}$ (Lucas, Lawes, 1998), and up to $300 \mu \mathrm{m}$ for larvae before settlement (Agassiz, 1862, Kakinuma, 1975). Planula metamorphosis into scyphistoma has been described in detail by Agassiz (1862).

It appears that Aurelia aurita can adjust its reproductive output in accordance with particular environmental situations. Lucas and Lawes (1998) found that medusae inhabiting a severely food-limited locality invested less energy into reproduction and produced a low number of large planula larvae ( $k$-strategy). In contrast, medusae from another locality with much greater food availability were able to direct more energy to reproduction, and produced a large number, but smaller planula larvae ( $r$-strategy).

\section{Asexual phase}

The asexual part of the life cycle is completed by the scyphistoma phenotype, which is capable of asexually reproducing (cloning) in at least three principal modes, i.e., (1) budding: a scyphistoma produces external outgrowths of various types that develop tentacles and other adult structures before detaching and becoming new scyphistomae (Perez, 1922; Renton, 1930; Gilchrist, 1937; Berrill 1949; Kakinuma, 1975); (2) strobilation: a scyphistoma transforms into strobila that produce several free-swimming ephyrae (Spanenberg, 1965, 1967, 1971; Kato et al., 1973; Olmon, Webb, 1974; Kakinuma, 1975); (3) production of free-swimming propagules = gemmation: a scyphistoma produces a spherical mass of cells internally from the lower stalk and stolons, or produces outgrowths externally; after a free-swimming stage, both spherical masses and outgrowths transform themselves into new scyphistomae (this study).

The production of podocysts may be considered another cloning mechanism in Aurelia aurita (Chapman, 1968; Lesh-Laurie, Suchy, 1990). Podocysts are encapsulated cuticular structures containing tissue of ectodermal and / 
or amebocyte origin formed at the scyphistoma attachment disk (Chapman, 1968, 1970). Scyphistomae produce two or three podocysts in about two days. Exposure to poor water quality and accumulation of algae and debris increase the cyst production, but even during favorable environmental conditions scyphistomae often produce cysts. The excystment process takes one or two days, and the further development into complete scyphistoma is similar to that already described for gemmae (personal observations).

In addition, Aurelia aurita has ample regenerating capabilities, particularly from isolated ectodermal fragments and tentacles, and from pedal stolons, into new complete scyphistoma (Gilchrist, 1937; Steinberg, 1963; Kakinuma, 1975; Lesh-Laurie, Suchy, 1990). LeshLaurie and Corriel (1973) suggested that the complete regeneration of scyphistomae from isolated tentacles represents another method of asexual reproduction.

\section{Larval diversity and direct development}

Significant differences in egg size have been reported and the effect of different egg sizes on particular embryo development has been discussed. Agassiz (1862) observed an important variation on the size of planula reaching brood pouches, but he did not follow planulae of different sizes through metamorphosis. Haeckel (1881) observed that Aurelia aurita produce eggs of different sizes, the smallest of which gastrulated by ingression and developed into the free-swimming planula larva. However, somre of the largest eggs gastrulated by incomplete invagination and developed directly into ephyrae (hypogenesis) (Haeckel, 1881 pp. 28, 29. Figs 21-24), while other large eggs developed directly into a free-swimming actinula (Haeckel, 1881 pp. 20. Fig. 7). In addition, an intermediate size egg developed into a large planula larva that produced more planulae by budding before settling (Haeckel, 1881 pp. 20. Figs 4-6).

Yasuda (1971) working with medusae collected in Urazoko Bay (Japan Sea) observed that some planula larvae developed into scyphistomae, but a higher proportion of planulae (released by the same medusa) developed into ephyrae, bypassing the scyphistoma stage. Mean values of planulae developing into ephyrae were $76 \%$ for medusae collected in April (size range: $15-26 \mathrm{~cm}$ ); $62 \%$ (collected in May, size range: $20-30 \mathrm{~cm}$ ); and $57 \%$ (collected in June, size range: $15-20 \mathrm{~cm}$ ). The time required for planulae to develop into ephyrae after settlement varied between 3 and 11 days depending on temperature, and the egg size varied between 260-300 $\mu \mathrm{m}$. Moreover, Kakinuma (1975) in one experiment observed that about $90 \%$ of the planulae extracted from medusae collected in Mutsu Bay, Japan and maintained in Petri dishes differentiated into ephyrae.

The life cycle of Aurelia aurita includes two principal larval forms; these different life forms increase flexibility in dispersal and adaptability during a critical period of ontogeny when the highest mortality may occur (Vance, 1973). The first type, the rather phylopatric and lecithotrophic sexually produced planula larva is released by the planktonic medusoid phase and spends a short period as part of the plankton, consequently decreasing the time to predation exposure, and avoiding dependence on external food supply. Although planulae dispersal is limited, at the time of larvae release, the parent medusae may have been drifting away from their localities of origin for several months. The second larval form, the free-swimming planktotrophic ephyra that normally are produced asexually through the metamorphic process of strobilation (transversal fission), but they also can originate from the sexual part of the cycle from the direct development of planula and actinula larvae. Depending upon ambient temperature, ephyrae normally take between 10 and 25 days before becoming young medusae (Agassiz, 1862; Spanenberg, 1965; personal observations). Ephyrae are the source of the primary dispersal stage of $A$. aurita, the medusae.

In addition, $A$. aurita may produce planula larvae capable of asexual reproduction. Haeckel (1881, pp. 19) described the vegetative multiplication of "gastrulae-larvae". He observed 
the production of larvae by splitting and budding of other larvae held in an aquarium during winter, although there was a large variation in settling time. By increasing the number of larvae that survive until settlement, this kind of larval reproduction enhances the probabilities of recruitment (Jaeckle, 1994). Furthermore, under the strawberry-coral model, which is intended for sessile organisms that multiply vegetatively in continuous habitats, and that sexually produce widely dispersed propagules (Williams, 1975), evolutionary success will require that vagile propagules establish themselves beyond clonal boundaries, and that they will need to be sexually produced. As Williams stated "only by genetically diversifying the widespread propagules is there any hope of producing any with sufficiently high local fitness" (Williams, 1975:31). Thus, by multiplying the same genet, larval reproduction offers an invaluable increase in the likelihood that a particular genetic combination will successfully complete metamorphosis and will establish a new local adapted clone.

\section{Life history strategy and evolutionary success}

Aurelia aurita's widespread geographical distribution includes all oceans, and extends from equatorial, and tropical latitudes (Kramp, 1955: Gulf of Guinea; Vanucci, 1957: Brazil; Rao, 1913: Andaman Islands, Indian ocean) to beyond the Arctic Circle in the Northern hemisphere (LeDanois, 1913: Iceland; Kramp, 1961 after Mac Ginitie, 1955: Point Barrow, Alaska). In the Southern hemisphere its reaches at least to the $38^{\text {th }}$ parallel in the South Atlantic (personal observations), and to South Australia in the Pacific ocean (Southcott, 1958). In addition, $A$. auritainhabits several seas that have been nearly isolated for long periods, e. g., the Red Sea (Ranson, 1945), the Baltic Sea (Ranson, 1945, Barz et al. 2006), the Black Sea (Kramp, 1961 after Valkanov, 1957), the Mediterranean Sea (Kramp, 1961 after Ranson, 1945), the Adriatic Sea (Vucetic, 1957), and the White Sea (Kramp, 1961 after Yashnov, 1948).
The cosmopolitan distribution ${ }^{2}$ of $A$. aurita suggests that its populations have adapted to a broad range of environmental parameters, (e. g., Miyake et al., 1997; Lucas, 2001) as well as having endured significant paleogeographic changes, likely through many vicariant and dispersal events. Fossils of scyphomedusae have been recovered from the lower Cambrian, and fossil Semaeostomatida are reported in Upper Jurassic(Moore, 1956); standard molecular clock analysis suggests that speciation in the genus Aurelia dates at least from tens of millions years before present and possibly up to 50-120 MYBP (Dawson, Jacobs, 2001). This evolutionary success may be explained in part on its complex life history, (Fig. 4) which involves not only metagenesis, i. e., the occurrence of both sexual and asexual generations, (Kramp, 1943) and hypogenesis, i.e., the direct transformation of gastrulae into ephyrae (Haeckel, 1881), but also because it includes two very distinct ecological types, i.e., a planktonic, highly dispersed, sexually produced medusa phenotype, and a benthic, sessile, scyphistoma phenotype that may combine various reproductive mechanisms, each associated with different dispersal capabilities:

1. Various budding processes increase the clone population (genotype) without varying its gene pool, which is already adapted to local conditions. As Francis (1979) pointed out, a genotype dispersed is less likely to be extermi-

\footnotetext{
${ }^{2}$ Recent studies have focused on the taxonomic status of Aurelia aurita (Dawson, Jacobs, 2001; Dawson, Martin, 2001; Schroth et al., 2002; Dawson, 2003). These molecular studies support the idea of a polytypic Aurelia composed of several cryptic species, cast doubts about the ubiquitous nature of $A$. aurita, and even suggest that lifehistory variability found in this species may be a reflection of different species adapted to local conditions. However, at least one of the identified molecular clades in each of the above mentioned studies had a cosmopolitan distribution, most of the other clades are very restricted geographically (some proposed clades inhabit areas that have been available for less than 10,000 years), and genetic differentiation was not found to be correlated with isolation by geographic distances. Even if the genetic differentiation found among the molecular clades (most of which were defined on a very limited sampling) represents distinct phylogenetic lineages (some of which have been hypothesized to have recently evolved through hybridization and even introgression events), there is no evidence that any of these putative species have developed localized physiological specializations or changes in their life cycles.
} 


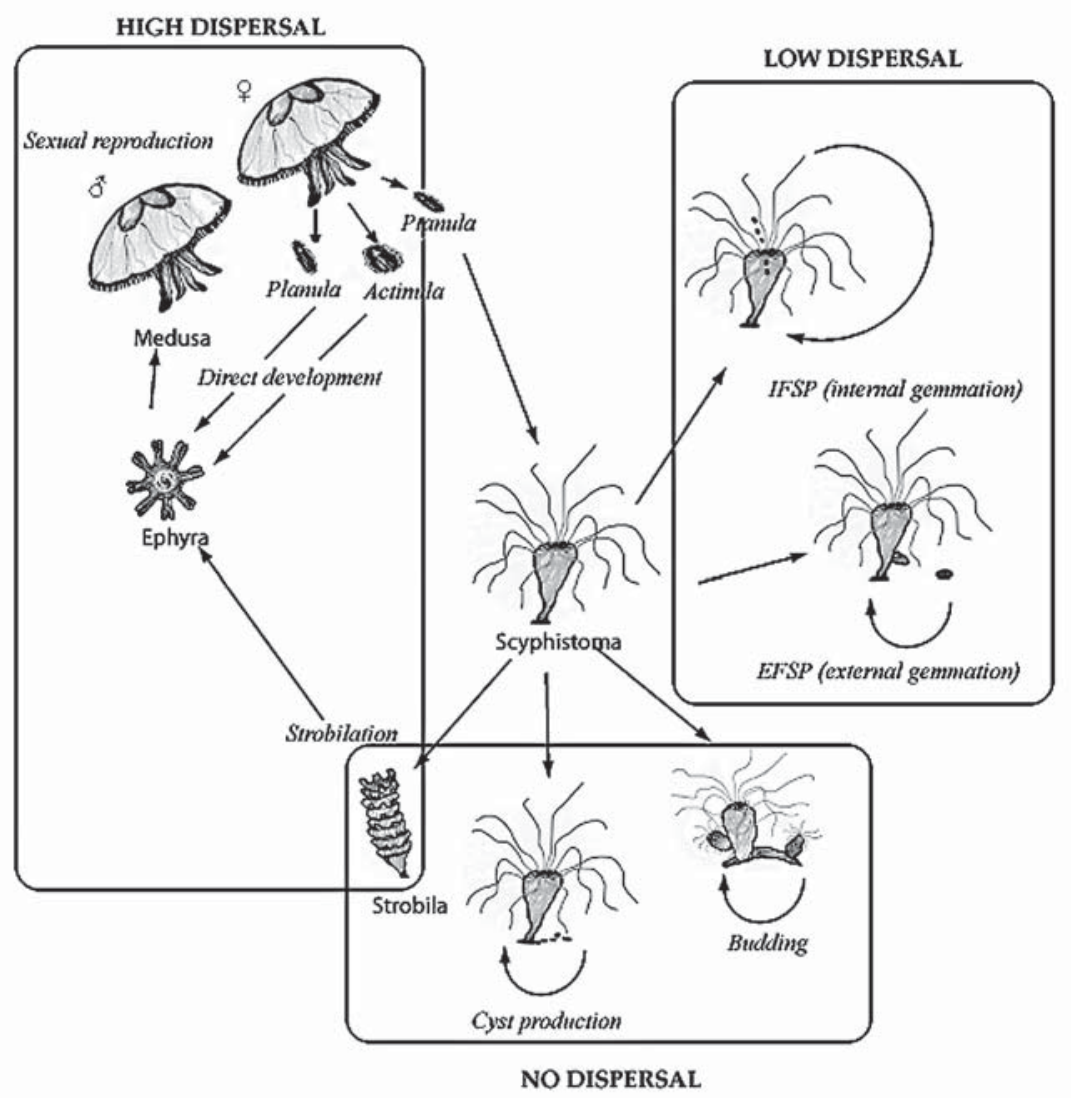

Fig. 4. The life cycle of Aurelia aurita (Linnaeus). It encompasses metagenesis, and the alternation of two dimorphic generations. In addition, it includes the presence of larval polymorphism, direct development, and several asexual reproductive mechanisms each associated with distinct dispersal capabilities.

Рис. 4. Жизненный цикл Aurelia aurita (Linnaeus). Он охватывает метагенез и чередование двух диморфных поколений. Жизненный цикл также включает личиночный полиморфизм, прямое развитие и несколько способов бесполого размножения, отличающиеся способностью к расселению.

nated. However, Tardent (1984) showed that genetic heterogeneity in cnidarians can also result from asexual reproduction. A mutation can "slip" into a forming bud; this mechanism eventually could lead to a sub-clone that contains only mutant cells, thus originating genoand phenotypic heterogeneity within a previously isogenetic clone. The same could be expected in relation with the other vegetative modes of reproduction, i.e., production of FSP (gemmation), strobilation and production of cysts. In addition, if mutations affect scyphistoma stem germinal cells, each time such scyphis- tomae strobilate they will produce several ephyrae that, when mature, will carry gametes with the mutant gene.

2. Strobilation and the development of a well-adapted phenotype to planktonic and drifting conditions allowed a widespread geographic dispersal, and the permanent colonization of zones no well suited for the benthic phenotype (Barz et al., 2006). Furthermore, the medusa form was able to exploit habitats richer in food and with greater gamete nourishing and distributing capacity (Chapman, 1966; Chapman, 1966 after Naumov, 1961). 
3. The production of free-swimming propagules combines characteristics of both budding and strobilation. Similar to budding, scyphistomae produce new ramets, but FSP (gemmae) are originated more rapidly and in larger quantities. And, like strobilation, the new organisms (FSP) pass directly to the plankton and disperse from the original population. However, in this case dispersal is restricted to a few weeks and therefore FSP will colonize relatively similar environments.

In addition, scyphistomae of Aurelia auri$t a$, as other sessile organisms, face challenging situations such as vulnerability to predators (Watanabe, Ishii, 2001), high levels of intraspecific competition (Grondahl, 1988), and a very restricted capacity of tropic response to a deteriorating environment. In such circumstances the production of cyst like structures (podocysts) has probably been an important survival factor. Finally, the occurrence of different larval forms with particular development, phenotype differentiation, and ecological role, offers additional flexibility to colonize new habitats and confront spatio-temporal environmental fluctuations.

\section{Acknowledgments}

I express my gratitude to Estela Lopretto for her advice, fruitful discussions and for helping to localize valuable bibliographic material. I thank all staff and volunteers from the NJAAS Research Lab that helped me during several years with the maintenance of the scyphistomae and medusae in the laboratory.

\section{References}

Agassiz L. 1860. Contribution to The Natural History of The United States of America. Vol.III. Part I. Acalephs in General. Boston: Little, Brown \& Co. London: Trubner \& Co.

Agassiz L. 1862. Contributions to The Natural History of the United States of America. Vol.IV. Part III. Discophore. Boston: Little, Brown \& Co. London: Trubner \& Co.

Avian M., Rottini Sandrini L. 1991. Oocyte development in four species of Scyphomedusae in northen Adriatic Sea // Hydrobiology. Vol.216/217. P.189-195.
Ayre D.J. 1984. The effects of sexual and asexual reproduction on geographic variation in the sea anemone Actinia tenebrosa // Oecologia. Vol.62. P.222-229.

Balcer L., Black R. 1991. Budding and strobilation in Aurelia (Scyphozoa, Cnidaria):

functional requirements and spatial patterns of nucleic acid synthesis // Rouxs's Archives of Developmental Biology. Vol.200. P.45-50.

Barz K., Hinrichsen H., Hirshe H. 2006. Scyphozoa in the Bornholm Basin (central Baltic Sea) - the role of advection// Journal of Marine Systems. Vol.60. Iss.12. P.167-176.

Berrill N. 1949. Developmental analysis of Scyphomedusae // Biological Reviews. Vol.24. P.393-410.

Bigelow R. 1900. The anatomy and development of Cassiopea xamachana // Proceedings of the Boston Society of Natural History. Vol.5 (6). P.191-236.

Calder D.R. 1973. Laboratory observations on the life history of Rhopilema verrilli (Scyphozoa: Rhyzostomeae) // Marine Biology. Vol.21. P.109-114.

Carre D., Carre C. 2000. Origin of germ cells, sex determination, and sex inversion in medusae of the genus Clytia (Hydrozoa, Leptomedusae): The influence of temperature // Journal of Experimental Zoology. Vol. 287. P.233-242.

Chapman D. 1966. Evolution of the scyphistomae // Rees W.J. (ed.) The cnidaria and their evolution. Symposium of the Zoological Society of London. Vol.16. P.51-75.

Chapman D. 1968. Structure, histochemestry and formation of the podocyst and cuticule of Aurelia aurita // Journal of Marine Biology Association of the United Kingdom. Vol.48. P.187-208.

Chapman D. 1970. Further observations on podocyst formation // Journal of Marine Biology Association of the United Kingdom. Vol.50. P.107-111.

Chuin T. 1930. Le cycle évolutif du scyphistome de Chrysaora: étude histophysiologique Trav.Stat.biol. Roscoff. Vol.8. P.1-179.

Claus C. 1893. Uber die Entwicklung des Scyphistoma von Cotylorhiza, Aurelia, und Chrysaora. I-II Art// Zoologischen Institut der Universität Wien.

Curtis S.K., Cowden R.R. 1971. Normal and experimentally modified development of buds in Cassiopea // Acta Embryologiae Experimentalis. Vol.3. P.239-259.

Dawson, M.N. 2003. Macro-morphological variation among cryptic species of the moon jellyfish, Aurelia (Cnidaria: Scyphozoa) // Marine Biology. Vol.143. P.369-379.

Dawson M.N., Jacobs D.K. 2001. Molecular evidence for cryptic species of Aurelia aurita (Cnidaria, Scyphozoa) // Biological Bulletin. Vol.200. P.92-96.

Dawson M.N., Martin L.E. 2001. Geographic variation and ecological adaptation in Aurelia (Scyphozoa, Semaeostomeae): some implications from molecular phylogenetics // Hydrobiologia. Vol.451. P.259-273.

Dawson M.N., Gupata A., England M. 2005. Coupled biophysical global ocean model and molecular genetic analyses identify multiple introductions of cryptogenic species // Proceedings of the Natural Academy of 
Science of the United States of America. Vol.102. P.11968-11973.

Eckelbarger K.J., Larson R.L. 1988. Ovarian morphology and oogenesis in Aurelia aurita (Scyphozoa: Semeaeostomae): ultrastructural evidence of heterosynthetic yolk formation in a primitive metazoan // Marine Biology. Vol.100. P.103-115.

Fautin D.G. 2002. Reproduction of Cnidaria // Canadian Journal of Zoology. Vol.80. P.1735-1754.

Francis L. 1979. Contrast between solitary and clonal lifestyles in the sea anemone Anthopleura elegantissima // American Society of Zoologists. Vol.19. P.669-681.

Gilchrist F. 1937. Budding and locomotion in the scyphistomae of Aurelia // Biological Bulletin. Vol.72. P.99-124.

Grondahl F. 1988. Interactions between polyps of Aurelia aurita and planktonic larvae of scyphozoans: an experimental study // Marine Ecological Progress Series. Vol.45. P.87-93.

Grondahl F. 1989 Evidence of gregarious settlement of planula larvae of the scyphozoan Aurelia aurita: an experimental study // Marine Ecological Progress Series. Vol.56. P.119-125.

Haeckel E. 1881. Metagenesis und Hypogenesis von $A u-$ relia aurita. Ein Beitrag zur Entwickelungsgeschichte und zur Teratologie der Medusen.

Hadzi J. 1912. Über die Podozysten der Scyphopolypen // Biol. Centralblatt. Vol.32. P.52-60.

Hadzi J. 1953. An attempt to reconstruct the system of animal classification // Systematic Zoology. Vol.2. No.4. P.145-154.

Hand C. 1959. On the origin and phylogeny of Coelenterates // Systematic Zoology. Vol.8. P.191-202.

Hamner W.M., Jenssen R.M. 1974. Growth, Degrowth and Irreversible Cell Differentiation in Aurelia aurita // American Zoologist. Vol.14. P.833-849.

Herouard E. 1907. Existence de statoblastes chez le schyphistome // Les Comptes rendus de l'Académie des sciences. T.65. P.601.

Herouard E. 1913. Relations entre la depression et la formation de pseudoplanula tentaculaires chez le schyphistome // Comptes Rendus Hebdomadaires des Séances de l'Académie des Sciences. Vol.156. P.1093-1095.

Hofmann D., Neumann R., Henne K. 1978. Strobilation,budding and initiation of scyphistomamorphogenesis in the rhizostome Cassiopea andromeda (Cnidaria: cyphozoa) // Marine Biology. Vol.47. P.161-176.

Hyman L.H. 1940. The Invertebrates: Protozoa through Ctenophora. New York: McGraw-Hill. 726 p.

Ishii H., Takagi A. 2003. Development time of planula larvae on the oral arms of the scyphomedusa Aurelia aurita // Journal of Plankton Research. Vol.25. P. $1447-1450$

Jackson J.B.C. 1986. Modes of dispersal of clonal benthic invertebrates: consequences for species'distributions and genetic structure of local populations // Bulletin of Marine Science. Vol.39. P.588-606.
Jackson J.B.C., Coates A.G. 1986. Life cycle and evolution of clonal (modular) animals // Philosophical Transactions Royal Society (London) Series B Biological Sciences. Vol.313. P.7-22.

Jaeckle W. 1994. Multiple Modes of Asexual reproduction by tropical and Subtropical Sea Star Larvae: an Unusual Adaptation for Genet Dispersal and Survival // Biological Bulletin. Vol.186. P.62-71.

Kakinuma Y. 1975. An experimental study of the life cycle and organ differentiation of Aurelia aurita Lamarck // Bulletin of the Marine Biological Station of Asamushi. Vol.15. No.3. P.101-113.

Kato K., Aochi M., Ozato K. 1973. Developmental aspects of strobilation in Aurelia aurita // Publishings of the Seto Marine Biology Laboratory. Vol.20. P.179-194.

Komai T. 1935. On Stephanoscyphus and Nausithoe // Memoirs of the College of Science Kyoto University Series B. Vol.10. P.290-339.

Kramp P.L. 1943. On development through alternating generations, specially in Coelenterata // Vidensk. Medd. dan Naturhist Foren. Vol.107. P.13-32.

Kramp P.L. 1955. The medusae of tropical west coast of Africa // Atlantide Report. Vol.3. P.239-324.

Kramp P.L. 1961. Synopsis of the Medusae of the World // Journal of the Marine Biological Association of the United Kingdom. Vol.40. P.1-469.

Lambert F. 1935. Jellyfish. The difficulties of the study of their life history and other problems // Essex Naturalist. Vol.25. P.70-86.

Lesh-Laurie G., Corriel R. 1973. Scyphistoma regeneration from isolated tentacles in Aurelia aurita // Journal of the Marine Biological Association of the United Kingdom. Vol.53 P.885-894.

Lesh-Laurie G., Suchy P. 1990. In: Harrison, F. \& J. Westfall (eds). Microscopy Anatomy of Invertebrates. Cnidaria: Scyphozoa and Cubozoa Vol.2. P.228-266.

Littlefield C.F. 1986. Sex determination in hydra: control by a subpopulation of interstitial cells in Hydra oligactis males // Developmental Biology. Vol.117. P.428-434.

Lucas C.H. 1996. Population dynamics of Aurelia aurita (Scyphozoa) from an isolated brackish lake, with particular reference to sexual reproduction // Journal of Plankton Research. Vol.18. P.987-1007.

Lucas C.H. 2001. Reproduction and life history strategies of the common jellyfish Aurelia aurita, in relation to its ambient environment // Hydrobiologia. Vol.451. P.229-246.

Lucas C.H., Lawes S. 1998. Sexual reproduction of the scyphomedusa Aurelia aurita in relation to temperature and variable food supply // Marine Biology. Vol.131. P.629-638.

Mc Fadden C. 1997. Contributions of sexual and asexual reproduction to population structure in the clonal soft coral, Alcyonium rudyi // Evolution. Vol.51. No.1. P.112-126.

Moore R.C. 1956. Scyphozoa // R.C.Moore (ed.) Treatise on Invertebrate Paleontology. Part F. Coelenterata. Geological Society of America \& University of Kansas Press. 508 p. 
Miyake H., Iwao K., Kakinuma Y. 1997. Life history and environment of Aurelia aurita // South Pacific Study. Vol.17. P.273-285.

Olmon J.E, Webb K.L. 1974. Metabolism of 131I in relation to strobilation of Aurelia Aurita (Scyphozoa) // Journal of Experimental Marine Biology and Ecology. Vol. 6. P.113-122.

Paspaleff G.W. 1938. Über die Entwicklung von Rhizostoma pulmo Agass // Arb biol Meeresst Varna. Vol.7. P.1-25.

Pechenik J.A. 1991. Biology of the Invertebrates. Second Edition. Dubuque, Iowa: William C. Brown Publishing. $567 \mathrm{p}$.

Perez C. 1922. Observations sur la multiplication gemminipare d'un scyphistome // Bulletin biologique de la France et de la Belgique. Vol. 56. P.245-274.

Rao H.S. 1913. Notes on Scyphomedusae in the Indian Museum // Records of the Indian Museum. Vol.33. P.25-62.

Renton R. 1930. On the budding of a scyphistoma // Proceedings of the Zoological Society of London. Vol.1930. P.893-896.

Russell F.S. 1970. The medusae of the Brithish Isles. II. Pelagic Scyphozoa with a supplement to the first volume on Hydromedusae. Cambridge: Cambridge University Press. 284 p.

Schroth W., Jarms G., Streit B., Schierwater B. 2002. Speciation and phylogeography in the cosmopolitan marine moon jelly, Aurelia sp // BioMed Central Evolutionary Biology. Vol.2. P.1-10.

Spanenberg D.B. 1965. Cultivation of the Life stages of Aurelia aurita under Controlled Conditions // Journal of Experimental Zoology. Vol.159. P.303-318.

Spanenberg D.B. 1967. Iodine induction of metamorphosis in Aurelia // Journal of Experimental Zoology. Vol.165. P.441-450.

Spanenberg D.B. 1971. Thyroxine induced metamorphosis in Aurelia // Journal of Experimental Zoology. Vol.178. P.183-194.

Spanenberg D.B. 1974. Thyroxine in early strobilation in Aurelia aurita// American Zoologist. Vol.14. P.825-831.

Steinberg S. 1963. The regeneration of whole polyps from ectodermal fragments of scyphistoma larvae of Aurelia aurita // Biological Bulletin. Vol.124. P.337-343.

Sugiura Y. 1963. On the life-history of rhizostome medusae. I. Mastigas papua L. Agassiz // Annotations Zoologicae Japonensis. Vol.36. P.194-202.
Tardent P. 1984. The significance of the metagenetic life cycles of Cnidaria for genetic diversification and adaptability // Engels et al. (eds.). Advances in Invertebrate Reproduction 3. Elsevier Science Publications. BV. P.269-278.

Thiel H. 1966. The evolution of Scyphozoa: A review // Ress W.J. (ed.). The Cnidaria and their evolution. New York: Academic Press. P.77-117.

Thorson G. 1950. Reproduction and larval ecology of marine bottom invertebrates // Biological Revisions. Vol.25. P.1-55.

Van Lieshout J., Martin V. 1992. Development of Planuloid Buds of Cassiopea xamachana (Cnidaria: Scyphozoa) // Transactions of the American Microscopical Society. Vol.111. No.2. P.89-110.

Vance R. 1973. On reproductive strategies in marine benthic invertebrates // The American Naturalist. Vol.107. P.339-352.

Vanucci M 1957. Distribuição de Scyphozoa nos costas do Brasil // Anais da Academia Brasileira de Ciencias. Vol.29. P.593-598.

Verwey J. 1960. Annual report of the zoological station of the Netherlands Zoological Society of the year 1958 // Archives Néerlandaises de Zoologie. Vol.13. P.556-571.

Vucetic T. 1957. Zooplankton investigations in the sea water lakes "Malo Jezero" and "Veliko Jezero" on the island of Mljet (1952-1953) // Acta Adriatica. Vol.6. P.1-51.

Watanabe T., Ishii H. 2001. In situ estimation of ephyrae liberated from polyps of Aurelia aurita using settling plates in Tokio Bay, Japan // Hydrobiologia. Vol.451. P.247-258.

Widersten B. 1965. Genital organs and fertilization in some Scyphozoa // Zoologiska Bidrag fran Uppsala. Vol.37. P.45-58.

Werner B. 1970. Contribution to the evolution in the genus Stephanoscyphus (Scyphozoa Coronatae) and ecology and regeneration qualities of Stephanoscyphus racemosus Komai // Publication of the Seto Marine Biological Laboratory. Vol.18. P.1-20.

Williams G.C. 1975. Sex and Evolution. Princeton, N.J.: Princeton University Press. 193 p.

Yasuda T. 1971. Monthly change in the bell-length composition and breeding season // Bulletin of the Japanese Society of Scientific Fisheries. Vol.37. No.5. P.364-370.

Responsible editors: F.D. Ferrari \& V.N. Ivanenko

Accepted October 24, 2007

Published online February 11, 2008 